\title{
Antioxidant Properties of Guava Varieties Grown under Salt Affected Soil
}

\author{
Kanthasamy Gurusamy*, Veerasamy Pushparaj Santhi, \\ Kabirdoss Indhumathi and Subbiah Parthiban
}
Department of Fruit Science, Horticultural College and Research Institute for Women, Tamil Nadu Agricultural University, Navalur Kuttapattu, Tiruchirappalli - 620 027, Tamil Nadu, India

*Corresponding author

\section{Keywords}

Guava fruit, Antioxidant, Free radicals and Vitamin C

\section{Article Info}

Accepted:

15 August 2020

Available Online:

10 September 2020

\begin{abstract}
A B S T R A C T
Antioxidants act as a defence mechanism that protect against deleterious effects of oxidative reaction produced by reactive oxygen species (ROS) in a biological system. In the present study, antioxidant effects were evaluated in guava fruit (Psidium guajava L.) extracts of three varieties viz. Lucknow 49, Allahabad Safeda and Arka Kiran. The enzymatic antioxidant (catalase, superoxide dismutase and guatathione peroxidise) and non enzymatic antioxidant (vitamin A, vitamin C \& vitamin E) activities were evaluated using reactive substance assay method. All the three extracts of guava varieties grown under salt affected soil possess the significant level of enzymic antioxidant activities. Among them SOD activity was found be high in Allahabad Safeda followed by Arka Kiran and Lucknow 49. Similar trend of CAT were observed in both Allahabad Safeda and Lucknow 49. Allahabad Safeda showed the maximum activity of GPX (1.61) followed by Arka Kiran (1.40) and Lucknow -49 (0.61). Non enzymatic antioxidants, Vitamin A content was found to be highest in Arka Kiran followed by Allahabad Safeda and the lowest level was found in Lucknow 49. The higher level of Vitamin C content was noted in Allahabad Safeda followed by Lucknow -49 and lower level was recorded in Arka Kiran. High vitamin E contents was observed in Allahabad Safeda (19.4 mg/ g tissue) followed by Lucknow 49 (17.53 mg /g tissue) and Arka Kiran (11.34 mg /g tissue). These findings reveal that guava fruits have potent antioxidant activities which may be responsible for its pharmacological effects.
\end{abstract}

\section{Introduction}

Nature has bestowed on us a very rich botanical wealth and a large number of diverse tupes of plants growing in different region of the world. For centuries, Plants have been used throughout the world as drugs and remedies for various diseases since they have greater potential for producing newer drugs of great benefit to mankind (Kuber et al., 2013). Antioxidants act as a defence mechanism that protect against deleterious effects of oxidative reaction produced by reactive oxygen species (ROS) in a biological system. Antioxidant constituents of the plant material act as radical scavengers, and help in converting the radical 
to less reactive species. Antioxidants are first line of defense against free radical damage and critical for maintaining optimum health and well being. A variety of free radical scavenging antioxidants is found in dietary sources like fruits and vegetables. Regular consumption of fruits and vegetables containing phytochemicals with potential antioxidant properties have been recognized as reducing the risk of human diseases such as cancer, atherosclerosis, arthritis, diabetes and other aging diseases (Jevas, 2016).

Psidium guajava or guava is a member of family Myrtaceae with 133 genera and more than 3,800 species. Different parts of plant contain variety of phytochemicals with various pharmacological properties (Jassal and Kaushal, 2019; Arya et al., 2012). Flowers are white, borne singly or in small clusters in the leaf axils. Flowers are $2-3 \mathrm{~cm}$ wide, with 4 or 5 white petals which are quickly shed, and a prominent tuft of perhaps 250 white stamens tipped with pale-yellow anthers (Tusof, 2003). The fruit, exuding a strong, sweet, musky odour when ripe, may be round, ovoid, or pear-shaped, $2.5-10 \mathrm{~cm}$ long, with 4 or 5 protruding floral remnants (sepals) at the apex with thin, light-yellow skin, frequently blushed with pink. Next to the skin is a layer of somewhat granular flesh, $1 / 8$ to $1 / 2$ inch thick, white, yellowish, lightor dark-pink, or near-red, juicy, acid, subacid, or sweet and flavorful.

The central pulp, slightly darker in tone, is juicy and normally filled with very hard, yellowish seeds, 1/8 inch long, though some rare types have soft, chewable seeds. Actual seed counts have ranged from 112 to 535 but some guavas are seedless or nearly so. When immature and until a very short time before ripening, the fruit is green, hard, gummy within and very astringent (Kamath et al., 2008). Guava rich in tannins, phenols, falvonoids, essential oils, lectins, vitamins and fatty acids etc. The therapeutic activity of guava is attributed to the presence of secondary metabolites. Flavonoids demonstrated antioxidant activity (Morton, 1987).

\section{Materials and Methods}

\section{Collection of fruit samples}

The fruit samples of three guava varieties were collected in the experimental plots of orchard, Horticultural College and Research Institute for Women, Tiruchirappalli, Tamil Nadu, India. The scientific name, family name, name of the varieties and parts used are shown in the Table 1.

\section{Preparation of the sample}

The matured fruits were collected and washed with water to remove impurities. Washed fruits were cut into small pieces. 100 gram of fruit was ground with $200 \mathrm{ml}$ of water using mixer and grinder. The suspension was centrifuged, the clear supernatant was used for the analysis of preliminary phytochemical screening, enzymatic and non enzymatic antioxidant activities.

\section{Chemicals}

All the chemicals used in the present study were of analytical reagent grade

\section{Preliminary phytochemical screening}

Preliminary phytochemical screening was carried out for the fruit extracts for their usual plant secondary metabolites using the standard methods (Peach and Tracey, 1955; Harborne, 1973). The screening was performed for alkaloids, flavonoids, saponins, phenols, steroids, glycosides and tannins. The precipitate formation or the colour intensity was used as analytical responses to these tests. 


\section{Estimation of biochemical parameters}

The fruit samples were used to analysed the antioxidant enzymes like SOD, CAT, GPX and non enzymatic antioxidants such vitamin A, vitamin $\mathrm{C}$ and Vitamin $\mathrm{E}$ according to the method of Das et al., (1965); Sinha, (1972); Beutler, (1984), Burtis and Ashwood, (19630; Nielsen, 2017; Deasi, (1989).

\section{Statistical analysis}

The experimental results were expressed as mean \pm standard deviation (SD) of three replicates. The data were subjected to one way analysis of variance (ANOVA) and the differences between samples were determined by Duncan's Multiple Range test using the Statistical package (SPSS). Statistical significance was set at $\mathrm{p}<0.05$.

\section{Results and Discussion}

\section{Preliminary phytochemical analysis}

The screening of plants for medicinal values has been carried out by number of workers with the help of preliminary phytochemical analysis. Phytochemical screening is paramount importance in identifying new source of therapeutically and industrially valuable compounds having medicinal significance, to make the best and judicious use of available natural wealth. Fruit samples of Psidium guajava have been phytochemically investigated and results are represented in the table 2 .

Phytochemical screening aqueous extract of Psidium guajava fruit samples revealed the presence of important bioactive compounds such as alkaloids, flavonoids, saponin, phenols and glycosides.

The flavanoids and polyphenolic compounds were abounded in all the three varieties of
Psidium guajava that may be responsible for its antioxidant and antidiabeteic activities.

\section{Enzymatic antioxidant activities}

SODs are a group of multimeric metalloenzymes that catalyzes the dissociation of superoxide radicals $\left(\mathrm{O}_{2}{ }^{-}\right)$to hydrogen peroxide $\left(\mathrm{H}_{2} \mathrm{O}_{2}\right)$ and molecular oxygen $\left(\mathrm{O}_{2}\right)$ in different parts of cells. Therefore, SOD is the main defense against the damage that is initiated by ROS. CATs and PODs are also significant scavengers of $\mathrm{H}_{2} \mathrm{O}_{2}$ and convert it to oxygen and water.

Table 3 represents the antioxidant enzymes such as SOD, CAT and GPX in the three varieties of fruit extracts of Psidium guajava. All the three extract possesses the significant level of activities of antioxidant enzymes.

Among them SOD activity was found high in Allahabad Safeda followed by Arka Kiran and Lucknow 49. Allahabad safeda and Lucknow 49 showed very similar catalase activities. Allahabad Safeda showed the maximum activity of GPX (1.61) followed by Arka Kiran (1.40) and Lucknow 49 (0.61).

Antioxidants are a group of secondary metabolites produced from plants to compete oxidative stress initiated by reactive oxygen species (ROS). A number of ROSs such as superoxide anion radicals and the hydroxyl radicals are generated during normal oxidation/reduction reactions as a result of aerobic metabolism.

An antioxidant system is naturally to scavenge such radicals. Many plants are able to exhibit antioxidant defense mechanisms including superoxide dismutase (SOD) (EC 1.15.1.1), catalase (CAT) (EC 1.11.1.6), peroxidase (POD) (EC 1.11.1.7) enzymes which work together to detoxify ROS (Moattar et al., 2016). 
Table.1 Details of Psidium guajava fruit samples

\begin{tabular}{|l|l|l|l|}
\hline Scientific name & Family name & Name of the varieties & Parts used \\
\hline Psidium guajava & Myrtaceae & Lucknow 49 & Whole Fruit \\
\cline { 3 - 3 } & & Arka kiran \\
\hline & & Allahabad safeda & \\
\hline
\end{tabular}

Table.2 Phytochemicals screening of fruit samples of Psidium guajava

\begin{tabular}{|r|l|c|c|c|}
\hline \multirow{2}{*}{ S. No } & \multirow{2}{*}{ Test } & \multicolumn{3}{|c|}{ Aqueous extracts of Psidium guajava } \\
\cline { 3 - 5 } & & Lucknow 49 & Arka Kiran & Allahabad Safeda \\
\hline $\mathbf{1}$ & Alkaloids & ++ & ++ & ++ \\
\hline $\mathbf{2}$ & Flavonoids & ++ & ++ & ++ \\
\hline $\mathbf{3}$ & Saponins & + & + & + \\
\hline $\mathbf{4}$ & Phenols & ++ & ++ & ++ \\
\hline $\mathbf{5}$ & Steroids & - & - & - \\
\hline $\mathbf{6}$ & Glycosides & + & ++ & ++ \\
\hline $\mathbf{7}$ & Tannins & - & - & - \\
\hline
\end{tabular}

(+) presence (-) absence

Table.3 Activities of enzymic antioxidants in selected guava fruit samples

\begin{tabular}{|c|l|l|l|l|}
\hline Sl.No. & \multicolumn{1}{|c|}{ Enzymic Antioxidant } & Lucknow 49 & \multicolumn{1}{|c|}{ Arka Kiran } & \multicolumn{1}{|c|}{ Allahabad Safeda } \\
\hline 1. & Superoxide dismutase (SOD) & $0.17 \pm 0.08$ & $0.89 \pm 0.09 \mathrm{a}^{*}$ & $1.29 \pm 0.72 \mathrm{~b}^{*} \mathrm{c}^{*}$ \\
\hline 2. & Catalase (CAT) & $1.17 \pm 0.26$ & $1.43 \pm 0.06 \mathrm{a}$ & $1.17 \pm 0.18 \mathrm{bc}$ \\
\hline 3. & Glutathione peroxidase (GPX) & $0.61 \pm 0.11$ & $1.40 \pm 0.07 \mathrm{a}^{*}$ & $1.61 \pm 0.54 \mathrm{~b}^{*} \mathrm{c}$ \\
\hline
\end{tabular}

The values are mean \pm SD of triplicates

a indicates comparison between Lucknow 49 and Arka kiran

b indicates comparison between Lucknow 49 and Allahabad safeda

c indicates comparison between Arka kiran 49 and Allahabad safeda

*indicates significant difference at $5 \%$ level $(\mathrm{p}<0.05)$

SOD: $50 \%$ inhibition of nitrite formed/ $\mathrm{min} / \mathrm{mg}$ protein

CAT: $\mu$ moles of $\mathrm{H}_{2} \mathrm{O}_{2}$ consumed/ $\mathrm{min} / \mathrm{mg}$ protein

GPX: $\mu$ moles of GSH oxidized / min/mg protein

Table.4 Vitamin A, Vitamin C and Vitamin E contents in selected guava fruit samples

\begin{tabular}{|c|l|c|c|c|}
\hline Sl.No. & \multicolumn{1}{|c|}{ Species } & $\begin{array}{c}\text { Vitamin A } \\
\text { (U/g tissue) }\end{array}$ & $\begin{array}{c}\text { Vitamin C } \\
\text { (mg/g tissue) }\end{array}$ & $\begin{array}{c}\text { Vitamin E } \\
\text { (mg/g tissue) }\end{array}$ \\
\hline 1. & Lucknow 49 & $435 \pm 0.03$ & $33.58 \pm 0.01$ & $17.53 \pm 0.19$ \\
\hline 2. & Arka Kiran & $506 \pm 0.04 \mathrm{a}^{*}$ & $28.14 \pm 0.51 \mathrm{a}^{*}$ & $11.34 \pm 0.15 \mathrm{a}^{*}$ \\
\hline 3. & Allahabad Safeda & $482 \pm 0.01 \mathrm{bc}$ & $38.07 \pm 0.21 \mathrm{~b}^{*} \mathrm{c}^{*}$ & $19.40 \pm 0.11 \mathrm{bc}^{*}$ \\
\hline
\end{tabular}

The values are mean \pm SD of triplicates

a indicates comparison between Lucknow 49 and Arka kiran

b indicates comparison between Lucknow 49 and Allahabad safeda

c indicates comparison between Arka kiran 49 and Allahabad safeda

*indicates significant difference at $5 \%$ level $(\mathrm{p}<0.05)$ 


\section{Non enzymatic antioxidant activities}

Medicinal plants may also produce nonenzymatic molecules including ascorbate, glutathione, carotenoids, tocopherol, retinol, polyphenolic compounds and flavonoids which eliminate, counteract and scavenge the ROS in plant systems and protect the main enzymes from ROS. Thus consumption of dietary antioxidants from these sources is beneficial in preventing diseases. The levels of vitamin contents in selected varieties of Psidium guajava are depicted in the table 4. In the present study, the Vitamin A content was found be maximum in Arka Kiran than Allahabad Safeda. The lowest level was found in Lucknow 49. The higher level of Vitamin C content was noted in Allahabad Safeda followed by Lucknow 49 and lower level was recorded in Arka Kiran. $19.4 \mathrm{mg} / \mathrm{g}$ tissue of vitamin E contents was observed in Allahabad Safeda, 17.53 and $11.34 \mathrm{mg} / \mathrm{g}$ tissue were noted in Lucknow 49 and Arka Kiran respectively.

In conclusion the based on the results obtained in the present study, it was concluded that the three varieties of Psidium guajava fruit extracts exhibited maximum presence of phytoconstituents. All the varieties are exhibited considerable amount of both enzymatic and non enzymatic antioxidant activities. Thus, Psidium guajava fruits can be considered as good source of antioxidants which might be beneficial for combating oxidative stress.

\section{Acknowledgement}

We are thankful to Honourable Vicechancellor of Tamil Nadu Agricultural University, Coimbatore, Tamil Nadu and The Dean, Horticultural college and Research Institute for Women, Tiruchirappalli for providing all necessary facilities to conduct the experiment.

\section{References}

Arya, V., Thakur, N. and Kashyap, C.P., Preliminary Phytochemical Analysis of the Extracts of Psidium Leaves, J. Pharmacognosy Phytochem. 1 (1), 1-4 (2012).

Beulter. In: Red cell metabolism - A manual of Biochemical methods ( $3^{\text {rd }}$ edn.) Gurnee and station, Orlando. (1984).

Burtis, C.A. and Ashwood, E.R. Tietz Textbook of Clinical Biochemistry, $2^{\text {nd }}$ edition, W.B. Sanders Company, Philadelphia, 1313-1314. (1986).

Das, S., Vasishat, S., Snehalatha, R., Das, N. and Srinivastava, L. M., Correlation between total antioxidant status and lipid peroxidation in hypercholesterolemia. Cur. Sci., 78, 486-487, (2000).

Desai, I., Vitamin E analysis methods for animal tissue. Methods of enzymology, 105, 138-143, (1989).

Harbone, J.B., Phytochemical Methods. London: Chapman and Hill; 17, (1973).

Jassal, K. and Kaushal, S., Phytochemical and antioxidant screening of Guava (Psidium guajava) leaf essential oil, Agriculture Research Journal 56 (3), 528-533, (2019).

Jevas C., The Role of Reactive Oxygen Species and Antioxidants in Oxidative Stress, Int. J. Res. Pharm. Biosci. 3 (6), $1-8,(2016)$.

Kamath, J.V., Nair, R. and Kumar, C.K.A., Psidium guajava L: A Review. Int. J. Gr. Pharm., 2 (1), 10-12, (2008).

Kuber, B.K., Lakshmi, M.R., Deepika, E. and Yamini, P. Phytochemcial Screening, In vitro antibacterial and antioxidant activity of the Psidium guajava root bark, Int. J.Curr.Microbiol.App.Sci., 2(10), 238-248, (2013).

Gurusamy, K., Kokilavani, R., Arumugasamy, K. and Sowmia, C., Non enzymatic antioxidant properties of 
ethanolic extract of polyherbal formulation (PHF) against $\mathrm{CCl} 4$ induced rats, Res. J. Biotech. 3(2), 5154, (2008).

Moattar, F.S, Sariri, R., Yaghmaee, P., Giahi, M., Enzymatic and Non-enzymatic Antioxidants of Calamintha officinalis Moench Extracts, J. Appl. Biotechn. Rept., 3(4), 489-494, (2016).

Morton, J. and Julia, F. M., Guava. In: Fruits of warm climates. Miami University, Miami, FL.356-363, (1987).

Nielsen, D., Food Analysis, Aspen
Publications, Inc. Gathersburg, Maryland, united State, Department of Agriculture Nutrient. (2017).

Peach, K. and Tracey, M. V., Modern Methods of Plant analysis, Springer Verlag, Berlin, 1(4), 373- 374. (1955).

Sinha, A.K., Colorimetric assay of catalse. Anal. Biochem., 47, 389-394, (1972).

Yusof, S., "Guavas". University Putra Malaysia, Selangor, Malaysia Elsevier Science Ltd, 2985-2991, (2003).

\section{How to cite this article:}

Kanthasamy Gurusamy, Veerasamy Pushparaj Santhi, Kabirdoss Indhumathi and Subbiah Parthiban. 2020. Antioxidant Properties of Guava Varieties Grown under Salt Affected Soil. Int.J.Curr.Microbiol.App.Sci. 9(09): 1775-1780. doi: https://doi.org/10.20546/ijcmas.2020.909.221 